\title{
SPOLEČENSKÁ ODPOVĚDNOST ORGANIZACE Z POHLEDU SPOLEČNOSTI POSKYTUJÍCÍ EXPRESNÍ KURÝRNÍ SLUŽBY: INTERPRETATIVNÍ PŘÍPADOVÁ STUDIE
}

\section{CORPORATE SOCIAL RESPONSIBILITY FROM THE PERSPECTIVE OF THE COMPANY PROVIDING EXPRESS COURIER SERVICES: INTERPRETATIVE CASE STUDY}

Dana Sommerauerová1 ${ }^{*}$, , Jan Chocholáč ${ }^{1}$

\begin{abstract}
Abstrakt
Problematika společenské odpovědnosti organizací (dále jen CSR) je v současné době velmi diskutovaným tématem. Implementace CSR do obchodní strategie může přispět ke zvýšení konkurenceschopnosti, která je nezbytná $v$ dnešním globalizovaném a moderním turbulentním tržním prostředí. Aplikace CSR v podnikání znamená, že organizace bere v úvahu také environmentální a sociální aspekty a dopady svých aktivit, produktů a služeb. CSR má vliv na to, jak zákazníci vnímají společnosti. Tento koncept je důležitý nejen pro zákazníky, ale také pro další zúčastněné strany, jako jsou: investoři, zaměstnanci, veřejnost, média, stát a další. Global Reporting Initiative (dále jen GRI) je nezávislá mezinárodní organizace, která je průkopníkem voblasti reportování udržitelnosti. Standardy GRI jsou první globální standardy pro podávání zpráv o udržitelnosti. Mají modulární vzájemně propojenou strukturu a predstavují globální osvědčené postupy pro podávání zpráv o řadě ekonomických, environmentálních a sociálních dopadů. Cílem tohoto přispěvku je doporučit přistup $k$ CSR pro společnost poskytující expresní kurýrní služby v České republice. Pozornost je primárně zaměřena na ekonomické, environmentální a sociální aspekty CSR, které tato společnost považuje za důležité z hlediska jejího podnikatelského sektoru. Metody interpretativní prrípadové studie, dotazníkového šetření a analytického sít’ového procesu (dále jen ANP) jsou použity k určení nejlepší strategie CSR pro společnost poskytující expresní kurýrní služby $v$ České republice $v$ souladu se standardy GRI.
\end{abstract}

Klíčová slova společenská odpovědnost organizací, Global Reporting Initiative, analytický sítový proces, interpretativní prípadová studie, globalizace, expresní kurýrní služby

Summary The issue of Corporate Social Responsibility (hereinafter CSR) is currently a highly discussed topic. The implementation of CSR in business strategy can contribute to increased competitiveness which is necessary in todays globalized and modern turbulent market environment. CSR application in business means that the company also takes into consideration environmental and social aspects and impacts of its activities, products and services. CSR has influence on how customers see companies. This concept is important not only for customers, but also for other stakeholders such as are

\footnotetext{
${ }^{1}$ Univerzita Pardubice, Dopravní fakulta Jana Pernera, Katedra dopravního managementu, marketingu a logistiky, Studentská 95, 53210 Pardubice, Česká republika

*korespondenční autor: dana.sommerauerova@student.upce.cz, tel +420 466036383
} 
the following: investors, employees, the general public, media, the state and other. The Global Reporting Initiative (hereinafter GRI) is an independent international organization that has pioneered sustainability reporting. The GRI Standards are the first global standards for sustainability reporting. They feature a modular, interrelated structure, and represent the global best practice for reporting on a range of economic, environmental and social impacts. The aim of this paper is to recommend an approach to CSR for a company providing express courier services Czech Republic. The attention is primarily focused on those economic, environmental and social aspects of CSR that are considered important by this company with regard to their business sector. The methods of interpretative case study, questionnaire survey and Analytic Network Process (hereinafter ANP) will be used to determine the best CSR strategy for the company providing express courier services in the Czech Republic in accordance with the GRI Standards.

Keywords Corporate Social Responsibility, Global Reporting Initiative, Analytic Network Process, interpretative case study, globalization, express courier services

\section{1 ÚVOD}

Problematika CSR je v poslední době rozsáhle diskutovaným tématem. Využití strategie CSR může představovat zásadní složku konkurenceschopnosti podniku. Aplikace CSR v podnikání znamená, že společnost bere v úvahu, kromě ekonomických, také environmentální a sociální aspekty a dopady svých aktivit a produktů. CSR má vliv na to, jak zákazníci vnímají společnosti a organizace. Dnešní zákazníci hledají nejen vysoce kvalitní produkty a služby, ale také sledují chování a strategii společností z hlediska jejich environmentálních a sociálních dopadů.

Tento koncept je důležitý nejen pro zákazníky, ale také pro další zainteresované strany, jako jsou: investoři, zaměstnanci, široká veřejnost, média, stát a další subjekty. V souladu s dnešním globalizovaným a moderním turbulentním tržním prostředím vyznačujícím se vysokou konkurencí se problematika CSR stává stále důležitější i pro společnosti poskytující expresní kurýrní služby, protože se jedná o vysoce konkurenční a globalizované odvětví.

Cílem tohoto příspěvku je doporučit přístup k CSR pro společnost poskytující expresní kurýrní služby v České republice. Pozornost je primárně zaměřena na ty ekonomické, environmentální a sociální aspekty CSR, které tato společnost považuje za důležité z hlediska jejího podnikatelského sektoru. Metody interpretativní případové studie, dotazníkového šetření a ANP jsou použity k určení nejlepší strategie CSR v souladu se standardy GRI.

\section{LITERÁRNÍ REŠERŠE}

Podle Hahn et al. (2015) se udržitelnost organizací a podniků stala populárním tématem ve výzkumu i praxi v posledních desetiletích. Stále větší pozornost je věnována dopadu na populaci a vyžaduje se, aby společnosti a organizace byly odpovědné za své obchodní činnosti, protože tyto činnosti ovlivňují životní prostředí, ekonomiku a lidstvo jako celek (Menichini a Rosati, 2014). Podle Zatwarnicka-Madura et al. (2019) je rozvoj orientace na CSR způsoben hlavně zvyšujícím se sociálním povědomím společností. Cho et al. (2017) dále uvádějí, že je obtížné definovat koncept a praxi CSR. Dahlsrud (2008) a Cho et al. (2017) se shodují, že neexistuje žádná jednotná ani široce přijímaná definice CSR. Dahlsrud (2008) poznamenává, že současné definice CSR jsou velmi konzistentní a jejich nesoulad je způsoben hlavně tím, jak jednotlivé společnosti CSR implementují.

Menichini a Rosati (2014) definují CSR jako manažerský přístup, který zajištuje odpovědnost a transparentnost pro společnosti a organizace usilující o takzvaný udržitelný rozvoj. CSR lze chápat jako odpovědné podnikání, přeneseně až jako svědomí společnosti nebo občanství společnosti; to představuje formu podnikové samoregulace integrované do obchodního konceptu (Wood, 1991). Podle McCarthyho 
et al. (2017) představuje tento koncept takové aktivity, které, jak se zdá, podporují určité sociální dobro, které přesahuje zájmy společnosti a které přesahuje požadavky, jež vyžaduje zákon. Norma ISO 26000 definuje CSR jako odpovědnost společností za dopady rozhodnutí a činností společností na společnost (lidstvo) a na životní prostředí; tato odpovědnost úzce souvisí s transparentním a etickým chováním společností (ISO, 2010).

CSR je velmi důležité téma $v$ globálním prostředí a jeho šíření je ovlivněno vztahy v dodavatelském řetězci, jak doplňují Chen et al. (2019). Řada společností se snaží integrovat do svých strategií a svých každodenních činností koncept CSR. Priority CSR se nepromítají pouze do fungování těchto jednotlivých společností, ale jsou také implementovány do dodavatelských řetězců (Ashby et al. 2012; Mani et al., 2016). CSR již není vnímána jako módní trend, ale představuje komplexní přístup k podnikání (Wu, 2002; Scherer a Palazzo, 2011). Podle autorů existuje rostoucí počet společností a organizací, které integrují CSR do svého dodavatelského řetězce, což je velmi náročné pro udržení rovnováhy mezi zisky, udržitelností životního prostředí a politikou sociální odpovědnosti podniků. Chen et al. (2019) poukazují na to, že implementace konceptu CSR je nejistá investice pro společnosti, protože nevědí, co jim náklady a př́nosy implementace filosofie CSR přinesou. Na druhé straně mnoho společností $\mathrm{v}$ současné době začíná alokovat prostředky na strategické aktivity CSR, protože si uvědomují, že jim to může pomoci zlepšit jejich ekonomické ukazatele vdlouhodobém horizontu (Lee, 2018).

Hahn et al. (2015) uvádí, že společnosti musí svou ekonomickou udržitelnost zaměřit stejně na ekonomické, environmentální a sociální aspekty, a že jeden aspekt nemůže mít přednost před ostatními, i když to často přináší problémy při rozhodování. Jak uvádí Menichini a Rosati (2014), výkon CSR závisí na těch dimenzích a zúčastněných stranách, které jsou skutečně ovlivněny aktivitami společnosti. Lee (2018) uvádí, že většina výzkumů CSR se zaměřuje především na vztahy se zákazníky a vztahy se zaměstnanci zůstávají do značné míry neprozkoumané. Podle autorů je vnímání aktivit CSR zaměstnanci velmi důležité pro vztahy na pracovišti, ale také pro výkon společnosti, protože zaměstnanci, kteří vnímají CSR příznivě, mají pozitivní vztah k organizaci v mnoha oblastech.

Implementace CSR podle Zatwarnicka-Madura et al. (2019) ovlivňuje celkovou marketingovou komunikaci společností na strategické i taktické úrovni. V současné době je důležité, aby se společnosti chovaly v souladu s principy CSR, ale zároveň své aktivity taktéž adekvátně sdělovaly veřejnosti (Cho et al., 2017). Reportování udržitelnosti je podle Menichini a Rosati (2014) klíčovou aktivitou při udržování efektivního vztahu mezi společností a zúčastněnými stranami. Cho et al. (2017) poukazují na to, že mnoho společností má v komunikaci CSR značné mezery a do komunikace CSR velmi často zahrnuje interní zpětnou vazbu. Pro zvýšení důvěryhodnosti komunikace v oblasti CSR byly vyvinuty různé standardy, přičemž standardy GRI patří mezi nejznámější a nejkomplexnější standardy a vyžadují, aby společnosti podávaly zprávy o ekonomických, environmentálních a sociálních dimenzích udržitelnosti (Menichini a Rosati, 2014).

Společnosti různých velikostí věnují pozornost konceptu CSR (malé, stř̌ední a velké společnosti). Tyto společnosti také pocházejí z řady průmyslových odvětví; jsou to výrobci nebo poskytovatelé služeb. Především od výrobců se očekává, že by to měli být oni, kdo by měl implementovat koncept CSR v nejširším smyslu tohoto konceptu: ochrana životního prostředí, řízení zaměstnanců, odpovědné řízení dodavatelského řetězce, charitativní dary, výhody pro zákazníka, rozvoj komunity, bezpečnost práce a zmírnění rizika produktů (Lindgreen et al., 2009). Tento článek se zaměřuje na poskytovatele expresních kurýrních služeb v České republice. Cílem tohoto příspěvku je doporučit přístup k CSR pro tuto společnost. 


\section{METODY}

V rámci tohoto článku jsou použity následující vědecké metody a prrístupy: interpretativní př́ípadová studie (podkapitola 3.1), analytický sít’ový proces (podkapitola 3.2) a standardy GRI voblasti CSR (podkapitola 3.3). Postup zpracování je následující: s využitím metody ANP budou transformovány aspekty CSR dle standardů GRI do jednotlivých sub-kritérií a kritérií v sít'ovém hierarchickém modelu, který bude obsahovat tři základní strategie CSR, tedy strategii pro oblast ekonomickou, environmentální a sociální. S využitím metody interpretativní případové studie bude tento postup aplikován na podniku poskytujícím expresní kurýrní služby v České republice scílem doporučit přístup k CSR pro tuto společnost.

\subsection{Interpretativní př́ípadová studie}

Problematika výběru vhodné CSR strategie pro podnik poskytující expresní kurýrní služby je ilustrována s použitím vědecké metody interpretativní případové studie. Povaha výzkumu ve společnostech je nejvhodnější pro interpretativní kvalitativní přístup, který může přinést bohaté porozumění klíčových otázkám minimalizací vzdálenosti mezi výzkumným pracovníkem a klíčovým rozhodujícím činitelem, vlastníkem / manažerem společnosti apod., za účelem praktického a teoretického porozumění a generování nových a alternativních teorií a konceptů (Bygrave, 1989).

Použití interpretativních př́padových studií je tedy pro explorativní výzkum naprosto oprávněné (Ponelis, 2015). Při použití interpretativních př́ípadových studií pro explorativní výzkum se klíčová rozhodnutí výzkumného pracovníka týkají předchozí teorie, analytických jednotek, počtu a výběru př́padů, technik, které mají být použity pro sběr dat, a metod, kterými budou shromážděná data analyzována (Eisenhardt, 1989). Tato rozhodnutí vedou k vytvoření protokolu př́padové studie, který pomáhá zajistit jednotnost výzkumných projektů (Maimbo a Pervan, 2005).

\subsection{Analytický sít’ový proces (ANP)}

Metoda ANP je dle Saaty a Vargas (2013), Saaty (1996) a Malviya, Kant a Gupta (2018) zjednodušením metody analytického hierarchického procesu (dále jen AHP z anglického Analytic Hierarchy Process), přičemž Sarkis (2003) dále dodává, že metoda ANP zvažuje závislost mezi jednotlivými prvky dané hierarchie. Saaty (1996) navrhl metodu ANP, aby bylo možné vzdát se některých omezení, která využívala metoda AHP, jak konstatují také Huang (2008) a Sarkis (2003).

U metody ANP mohou existovat závislosti mezi všemi úrovněmi, respektive klastry. Zároveň je dle autorů možné, že klastr může mít vazbu sám na sebe, jedná se tedy o vnitřní závislost prvků. Rozdíl mezi př́stupy metody AHP a ANP je znázorněn na obrázku 1.
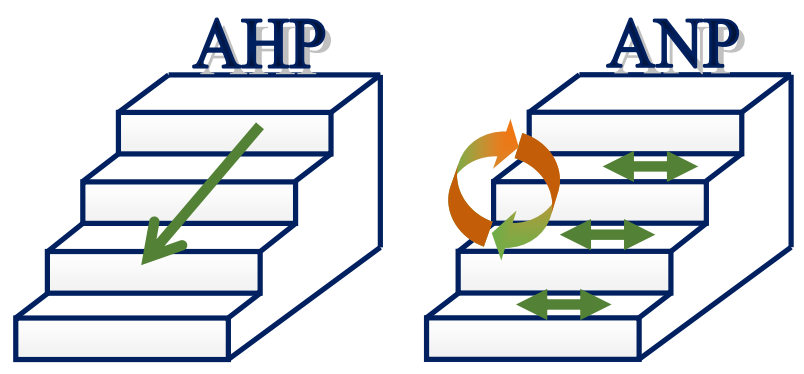

Obr. 1 Rozdíl mezi př́stupy AHP a ANP; zdroj: Bottero et al. (2008)

Použití metody ANP je dle Sharma a Garg (2015) velmi vhodné zejména proto, že u mnoha rozhodovacích problémů nepostačuje hierarchické strukturování, protože zahrnují interakci a závislost prvků vyšší úrovně v hierarchii prvků nižší úrovně. Metoda ANP je řešena s využitím softwarového nástroje SuperDecisions (v2.10), což je jediný volně použitelný softwarový nástroj vhodný pro tyto metody, vyvinutý týmem tvůrce těchto metod, kterým byl Thomas L. Saaty. 


\subsection{Standardy GRI v oblasti CSR}

Standardy GRI jsou prvními standardy pro podávání zpráv o udržitelnosti (GRI, 2020), přičemž společnosti používají standardy GRI k hlášení svých ekonomických, environmentálních a sociálních dopadů. Standardy GRI jsou rozděleny do čtyř podskupin: GRI 100 (univerzální podskupina), GRI 200 (ekonomická podskupina), GRI 300 (environmentální podskupina) a GRI 400 (sociální podskupina). $V$ tomto článku bude pozornost věnována pouze třem z těchto podskupin, tedy podskupině GRI 200, GRI 300 a GRI 400, přičemž jednotlivé podskupiny a jejich aspekty jsou přehledně zobrazeny v tabulce 1.

Tab. 1 Přehled aspektů CSR dle GRI; zdroj: GRI (2020)

\begin{tabular}{|c|c|c|c|}
\hline Číslo a popis aspektu dle GRI & Ekonomický & Environmentální & Sociální \\
\hline GRI 201 Ekonomická výkonnost & $\mathbf{X X X}$ & & \\
\hline GRI 202 Pozice na trhu & $\mathbf{X X X}$ & & \\
\hline GRI 203 Nepřímé ekonomické dopady & $\mathbf{X X X}$ & & \\
\hline GRI 204 Proces nakupování & $\mathbf{X X X}$ & & \\
\hline GRI 205 Protikorupční opatření & $\mathbf{X X X}$ & & \\
\hline GRI 206 Protikonkurenční chování & $\mathbf{X X X}$ & & \\
\hline GRI 301 Materiály & & $\mathbf{X X X}$ & \\
\hline GRI 302 Energie & & $\mathbf{X X X}$ & \\
\hline GRI 303 Voda & & $\mathbf{X X X}$ & \\
\hline GRI 304 Biodiverzita & & $\mathbf{X X X}$ & \\
\hline GRI 305 Emise & & $\mathbf{X X X}$ & \\
\hline GRI 306 Odpadní vody a odpady & & $\mathbf{X X X}$ & \\
\hline GRI 307 Environmentální dodržování zákonů & & $\mathbf{X X X}$ & \\
\hline GRI 308 Hodnocení dodavatelů & & $\mathbf{X X X}$ & \\
\hline GRI 401 Zaměstnanost & & & $\mathbf{X X X}$ \\
\hline GRI 402 Vztahy na pracovišti & & & $\mathbf{X X X}$ \\
\hline GRI 403 Bezpečnost a ochrana zdraví při práci & & & $\mathbf{X X X}$ \\
\hline GRI 404 Školení a vzdělávání & & & $\mathbf{X X X}$ \\
\hline GRI 405 Rozmanitost a rovné př́ležitosti & & & $\mathbf{X X X}$ \\
\hline GRI 406 Nediskriminace & & & $\mathbf{X X X}$ \\
\hline GRI 407 Svoboda sdružování a kolektivní vyjednávání & & & $\mathbf{X X X}$ \\
\hline GRI 408 Dětská práce & & & $\mathbf{X X X}$ \\
\hline GRI 409 Nucená nebo povinná práce & & & $\mathbf{X X X}$ \\
\hline GRI 410 Bezpečnostní postupy & & & $\mathbf{X X X}$ \\
\hline GRI 411 Práva domorodého obyvatelstva & & & $\mathbf{X X X}$ \\
\hline GRI 412 Ochrana lidských práv & & & $\mathbf{X X X}$ \\
\hline GRI 413 Místní komunita & & & $\mathbf{X X X}$ \\
\hline GRI 414 Posouzení sociálního zabezpečení dodavatelů & & & $\mathbf{X X X}$ \\
\hline GRI 415 Veřejná politika & & & $\mathbf{X X X}$ \\
\hline GRI 416 Zdraví a bezpečnost zákazníků & & & $\mathbf{X X X}$ \\
\hline GRI 417 Marketing a označování produktů & & & $\mathbf{X X X}$ \\
\hline GRI 418 Ochrana osobních údajů zákazníků & & & $\mathbf{X X X}$ \\
\hline GRI 419 Socioekonomické dodržování předpisů & & & $\mathbf{X X X}$ \\
\hline
\end{tabular}




\section{VÝSLEDKY}

Interpretativní př́padová studie (teoreticky vymezená v podkapitole 3.1) byla provedena ve společnosti poskytující expresní kurýrní služby, která sídlí na území České republiky, v období od 8. do 24. 9. 2020.

Standardy GRI v oblasti CSR (viz podkapitola 3.3) byly transformovány do podoby analytického sít'ového modelu s využitím metody ANP (viz podkapitola 3.2), viz obrázek 2.

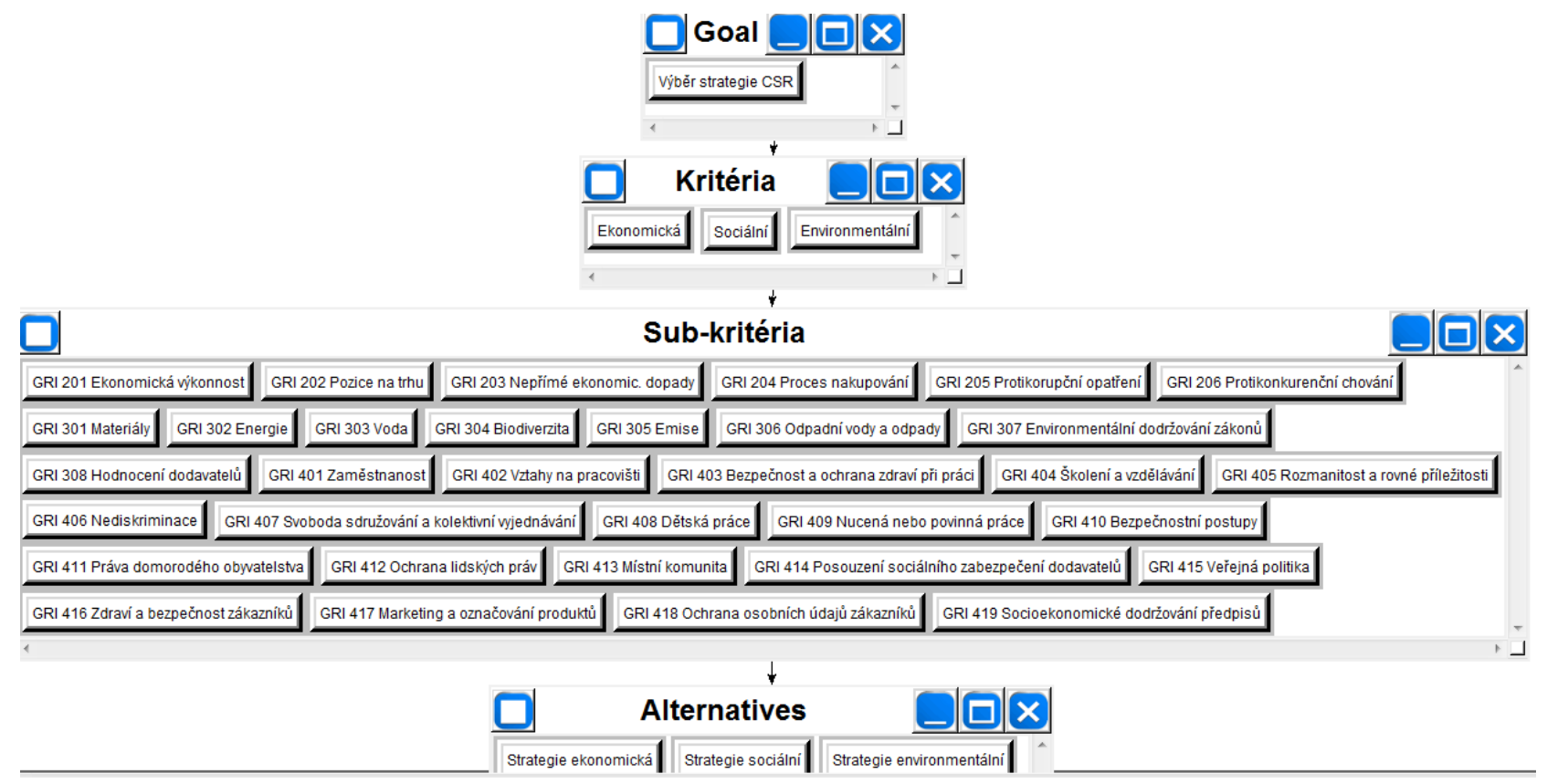

Obr. 2 ANP model; zdroj: autoři

Cílem sestaveného modelu je „výběr strategie CSR“ pro sledovaný podnik. Jako kritéria byly zvoleny jednotlivé podskupiny standardů GRI, tedy: GRI 200 (ekonomická podskupina), GRI 300 (environmentální podskupina) a GRI 400 (sociální podskupina). Jako sub-kritéria byly zvoleny jednotlivé aspekty CSR dle GRI, viz tabulka 1 . Za alternativy byly zvoleny tři možné strategie CSR dle GRI, tedy strategie ekonomická, sociální a environmentální. Nakonec byly mezi jednotlivými klastry (cíl / goal, kritéria, sub-kritéria a alternativy / alternatives) doplněny příslušné vazby, čímž vznikl analytický sít’ový model. Model (viz obrázek 2) byl sestaven s využitím softwarového nástroje SuperDecisions (v2.10), přičemž byla provedena kontrola logické struktury modelu s pozitivním výsledkem.

Metoda ANP je založena na provádění mnoha sérií párových porovnávání jednotlivých objektů obsažených v sestaveném modelu formou dotazníku. Tato párová porovnávání byla provedena v softwarovém nástroji SuperDecisions (v2.10), přičemž je prováděly tři osoby ze sledované společnosti: obchodní manažer, dispečer a speditér. U všech třech osob byla předpokládána rovnocenná kompetentnost ve vztahu k řešenému problému.

Po provedení veškerých párových porovnávání všemi osobami byla zkontrolována s využitím softwaru konzistence všech sestavených matic párových porovnávání. Zároveň byla provedena opětovná kontrola modelu a kontrola provedení všech párových porovnávání. Vzhledem ke skutečnosti, že všechny matice byly konzistentní a model nevykazoval žádnou chybu, tak bylo možné přikročit k:

- vygenerování nevážené supermatice modelu,

- vygenerování vážené supermatice modelu,

- vygenerování limitní matice modelu,

- vygenerování výsledného pořadí alternativ. 
V tabulce 2 je uvedeno výsledné pořadí alternativ získané ze softwarového nástroje SuperDecisions (v2.10) na základě provedených párových porovnávání třemi osobami ze sledované společnosti. Z tabulky je patrné, že jako nejlepší strategie byla vybrána strategie CSR v oblasti sociální (výsledná hodnota 0,4106), následovaná strategií CSR voblasti environmentální (výsledná hodnota 0,3742) a strategií CSR v oblasti ekonomické (výsledná hodnota 0,2152).

Tab. 2 Výsledné pořadí alternativ; zdroj: autoři s využitím SuperDecisions (v2.10)

\begin{tabular}{lcc}
\hline Alternativa & Hodnota & Pořadí \\
\hline Strategie ekonomická & 0,2152 & 3. \\
Strategie sociální & 0,4106 & 1. \\
Strategie environmentální & 0,3742 & 2. \\
\hline
\end{tabular}

Z tabulky 2 dále vyplývá, že mezi strategií sociální a environmentální je pouze nepatrný rozdíl z hlediska jejich preference. Na druhé straně strategie CSR v oblasti ekonomické je od obou předchozích strategií z hlediska jejího preferování poměrně vzdálená. Sledované společnosti, poskytující expresní kurýrní služby, je vrámci této interpretativní případové studie tedy doporučeno zaměřit se na přístup k CSR v oblasti sociální, respektive zvolit sociální strategii.

\section{ZÁVĚR}

Podniky si stále více začínají uvědomovat důležitost jejich přístupu k CSR a proto se ve větší míře začínají zaměřovat na všechny tři pilíře udržitelného rozvoje. Dříve se podniky zaměřovaly především na environmentální oblasti, ale v současné době věnují velkou pozornost také ekonomické a sociální oblasti.

Standardy GRI v oblasti CSR byly transformovány do podoby analytického sít’ového modelu s využitím metody ANP, čímž byla zároveň zajištěna objektivizace subjektivity při dotazníkovém šetření ve sledované společnosti. Cílem tohoto příspěvku bylo doporučit přístup $\mathrm{k}$ CSR pro společnost poskytující expresní kurýrní služby v České republice. Z provedené interpretativní př́ípadové studie vyplynulo, že pro sledovanou společnost je v rámci jejího př́ístupu k CSR dủležité zaměřit se především na environmentální a sociální oblast, přičemž největší důraz by měl být kladen na oblast sociální.

\section{Poděkování}

Tento článek byl publikován v rámci řešení vědecko-výzkumného projektu Univerzity Pardubice č. SGS_2020_010. Autoři děkují za poskytnutou podporu.

\section{Literatura}

Ashby, A., Leat, M. a Hudson-Smith, M. 2012. Making connections: a review of supply chain management and sustainability literature. Supply Chain Management: An International Journal, 17(5), s. 497-516. <https://doi.org/10.1108/13598541211258573>

Bottero, M., Lami, I. M. a Lombardi, P. 2008. Analytic network process: la valutazione di scenari di trasformazione urbana e territoriale. Citta di Castello: Genesi Gruppo editoriale.

Bygrave, W. D. 1989. The entrepreneurship paradigm (I): A philosophical look at its research methodologies. Entrepreneurship Theory and Practice, 14(1), s. 7-26. <https://doi.org/10.1177/104225878901400102>

Dahlsrud, A. 2008. How Corporate Social Responsibility is Defined: An Analysis of 37 Definitions. Corporate social responsibility and environmental management, 15(1), s. 1-13. <https://doi.org/10.1002/csr.132> 
Eisenhardt, K. M. 1989. Building theories from case study research. Academy of Management Review, 14(4), s. 532-550. <https://doi.org/10.2307/258557>

GRI. C 2020. Global Reporting Initiative. [Online]. Dostupné z: https://www.globalreporting.org/Pages/default.aspx [cit.: 2020, 6. záŕí].

Hahn, T., Pinkse, J., Preuss, L. et al. 2015. Tensions in Corporate Sustainability: Towards an Integrative Framework. Journal of Business Ethics, 127(2), $\quad$ s. 297-316. <https://doi.org/10.1007/s10551-014-2047-5>

Huang, J. J. 2008. A matrix method for the fuzzy analytic network process. International Journal of Uncertainty Quantification, 16(6), s. 863-878. <https://doi.org/10.1142/S0218488508005662>

Chen, Y., Chiu, S., Lin, S. et al. 2019. Corporate social responsibility and income smoothing: Supply chain perspectives. Journal of Business Research, 97, s. 76-93. <https://doi.org/10.1016/j.jbusres.2018.12.052>

Cho, M., Furey, L. D. a Mohr, T. 2017. Communicating Corporate Social Responsibility on Social Media: Strategies, Stakeholders, and Public Engagement on Corporate Facebook. Business and Professional Communication, 80(1), s. 52-69. <https://doi.org/10.1177/2329490616663708>

International Standards Office (ISO). 2010. Guidance on Social Responsibility. ISO 26000. Ženeva: ISO.

Lee, K. 2018. Valuations and Decisions of Investing in Corporate Social Responsibility: A Real Options Viewpoint. Sustainability, 10(10). <https://doi.org/10.3390/su10103532>

Lindgreen, A., Swaen, V. a Johnston, W. J. 2009. Corporate social responsibility: an empirical investigation of U.S. organizations. Journal of Business Ethics, 85, s. 303-323. <https://doi.org/10.1007/s10551-008-9738-8>

Maimbo, H. a Pervan, G. 2005. Designing a case study protocol for application in IS research. Proceedings of the Ninth Pacific Asia Conference on Information Systems, s. 1281-1292. <http://www.pacis-net.org/file/2005/113.pdf>

Malviya, R. K., Kant, R. a Gupta, A. D. 2018. Evaluation and Selection of Sustainable Strategy for Green Supply Chain Management Implementation. Business Strategy and the Environment, 27(4), s. 475-502. <https://doi.org/10.1002/bse.2016>

Mani, V. et al. 2016. Social sustainability in the supply chain: construct development and measurement validation. Ecological Indicators, 71, s. 270-279. <https://doi.org/10.1016/j.ecolind.2016.07.007>

McCarthy, S., Oliver, B. a Song, S. 2017. Corporate social responsibility and CEO confidence. Journal of Banking \& Finance, 75, s. 280-291. <https://doi.org/10.1016/j.jbankfin.2016.11.024>

Menichini, T. a Rosati, F. 2014. A fuzzy approach to improve CSR reporting: an application to the Global Reporting Initiative indicators. Procedia Social and Behavioral Sciences, 109, 355-359. <https://doi.org/10.1016/j.sbspro.2013.12.471>

Ponelis, S. R. 2015. Using interpretive qualitative case studies for exploratory research in doctoral studies: A case of Information Systems research in small and medium enterprises. International Journal of Doctoral Studies, 10, s. 535-550. <https://doi.org/10.28945/2339>

Saaty, T. L. 1996. Decision Making with Dependence and Feedback: the Analytic Network Process. Pittsburgh: RWS.

Saaty, T. L. a Vargas, L. G. 2013. Decision Making with the Analytic Network Process. New York: Springer.

Sarkis, J. 2003. A strategic decision framework for green supply chain management. Journal of Cleaner Production, 11(4), s. 397-409. <https://doi.org/10.1016/S0959-6526(02)00062-8> 
Sharma, R. a Garg, S. 2015. Selecting the best operational strategy for job shop system: an ANP approach. International Journal of Industrial and Systems Engineering, 20(2), s. 231-262. <https://doi.org/10.1504/IJISE.2015.069544>

Scherer, A. G. a Palazzo, G. 2011. The new political role of business in a globalized world: A review of a new perspective on CSR and its implications for the firm, governance, and democracy. Journal of Management Studies, 48(4), s. 899-931. <https://doi.org/10.1111/j.1467-6486.2010.00950.x>

Wood, D. J. 1991. Corporate social performance revisited. The Academy of Management Review, 16(4), s. 691-718. <https://www.jstor.org/stable/258977>

$\mathrm{Wu}, \mathrm{C}$. F. 2002. The relationship of ethical decision-making to business ethics and performance in Taiwan. Journal of Business Ethics, 35(3), s. 163-176. <https://doi.org/10.1023/A:1013853107403>

Zatwarnicka-Madura, B., Siemieniako, D., Glinska, E. et al. 2019. Strategic and Operational Levels of CSR Marketing Communication for Sustainable Orientation of a Company: A Case Study from Bangladesh. Sustainability, 11(2). <https://doi.org/10.3390/su11020555> 